\title{
RODITELJSKI NADZOR I PONAŠANJE DJEVOJČICA I DJEČAKA NA INTERNETU
}

\author{
Ivana Lagator \\ Vinkovci, Hrvatska \\ Doc. dr. sc. Danijela Šincek \\ Sveučilište Josipa Jurja Strossmayera u Osijeku \\ Filozofski fakultet u Osijeku \\ Osijek, Hrvatska \\ Ivana Duvnjak, asistentica \\ Sveučilište Josipa Jurja Strossmayera u Osijeku \\ Filozofski fakultet u Osijeku \\ Osijek, Hrvatska
}

\section{Sažetak:}

Cilj ovog istraživanja bio je ispitati odnos roditeljskog nadzora i spola sudionika s nekim ponašanjima na internetu. $U$ istraživanju je sudjelovalo 388 učenika četvrtih razreda osnovnih škola. Rezultati pokazuju kako djeca percipiraju visoku razinu roditeljskog nadzora. Učenici koji percipiraju višu razinu roditeljskog nadzora provode više vremena dnevno u dopisivanju s prijateljima i u traženju zanimljivih podataka, češće pronalaze motivaciju za pristupanje internetu u traženju informacija vezanih za školu i druženju te češće objavljuju sadržaje na društvenim mrežama od učenika koji percipiraju nižu razinu roditeljskog nadzora. Prilikom ispitivanja spolnih razlika utvrđeno je kako dječaci češće izražavaju kako imaju otvoren Facebook profil, provode više vremena na internetu radnim danom i vikendom od djevojčica te češće igraju igrice, objavljuju postove i traže zanimljive podatke. Osim toga, češće pronalaze motivaciju za pristup internetu u otklanjanju dosade i želji da ne budu drugačiji od drugih, a i češće navode kako ne mogu bez interneta, dok djevojčice češće pristupaju internetu u obrazovne svrhe. Rezultati su pokazali kako dječaci češće objavljuju različite sadržaje na društvenim mrežama i češće otkrivaju osobne informacije na Facebooku, dok u percipiranoj razini roditeljskog nadzora nisu utvrđene spolne razlike. Ovi podaci mogu pridonijeti boljem razumijevanju uloge roditelja u korištenju interneta kod djece.

Ključne riječi: društvene mreže, ponašanja djece na internetu, roditeljski nadzor

\section{PONAŠANJE DJECE NA INTERNETU}

Sve veći broj djece svakodnevno se služi internetom. Istraživanje provedeno u 25 europskih zemalja (EU Kids Online; Livingstone, Haddon, Görzig, i Ólafsson, 2011) pokazalo je kako se $93 \%$ djece u dobi od 9 do 16 godina aktivno služe internetom, pri čemu ih $60 \%$ pristupa internetu svakodnevno, dok je starije UNICEF-ovo istraživanje (2008) pokazalo je kako većina učenika (96\%) ima vlastiti mobitel i računalo (95\%), pri čemu $48.3 \%$ djece navodi kako svakodnevno pristupa internetu. Novije istraživanje provedeno na učenicima osmih razreda pokazuje kako ih se većina koristi internetom svaki dan (71.5\%), pri čemu se njime najčešće služe jedan do dva sata dnevno (43.4\%), zatim tri do četiri sata (26.2\%), a najmanji udio (9\%) služi se internetom pet i više sati (Puharić, Stašević, Ropac, Petričević i Jurišić, 2014). Učenici viših razreda 
osnovne škole provode na internetu gotovo tri sata dnevno, pri čemu najčešće pristupaju internetu preko mobitela (Šincek, Tomašić Humer i Duvnjak, 2015).

Pritom se najveći postotak mladih internetom koristi u svrhu komunikacije s prijateljima, zatim za skidanje različitih sadržaja te za pretraživanje materijala potrebnog za školu i učenje (Livingstone i sur., 2011; Haddon i Livingstone, 2012). DeBell i Chapman (2006) su utvrdili da $56 \%$ učenika navodi kako se koristi računalom za igranje igrica, $47 \%$ za školske zadaće, dok ih $45 \%$ koristi u svrhu povezivanja na internet, dok se u hrvatskim istraživanjima pokazuje kako se najveći broj učenika koristi internetom za upoznavanje novih prijatelja te za slušanje i presnimavanje filmova i glazbe (UNICEF, 2008; Puharić i sur., 2014). Djeca često izvještavaju o tome kako se na internetu dopisuju s prijateljima s kojima se i inače druže (92\%) te internet postaje dopunski medij za održavanje kontakata (Gross, Juvonen, i Gable, 2002). Djeca u dobi od deset i jedanaest godina prilikom služenja internetom najčešće igraju igrice, gledaju videouratke, pretražuju i skidaju slike, pretražuju web stranice i dopisuju se s prijateljima (Tabone i Messina, 2010). Izbjegavanje dosade jedan je od glavnih motiva za korištenje interneta kod djece (ChienHsin, Shong-Lin, i Chin-Pi, 2009). Vuletić, Jeličić i Karačić (2014) utvrdili su kako 92\% sudionika raspona dobi od 11 do 18 godina kao glavnu svrhu korištenja interneta navodi razonodu, a tek $8 \%$ školu.

Pri korištenju društvenim mrežama, osobito kad se uzme u obzir objavljivanje osobnih informacija na njima, važno je imati na umu rizike koje takvo ponašanje može imati po sigurnost, osobito učenika. Izostanak osobnog kontakta sa sugovornicima i osobama koje mogu pratiti objave, daju djeci lažni osjećaj sigurnosti i treba ih educirati o opasnostima otkrivanja osobnih informacija na internetu, jer već na temelju nekoliko informacija potencijalno zlonamjerna osoba može pronaći mjesto gdje dijete živi ili ide u školu (Robotić, 2015). Edukacija o sigurnosti na internetu uključuje poduku o neodgovaranju na sumnjive poruke, neprihvaćanju nepoznatih zahtjeva za prijatelje na društvenim mrežama, kao i da objavljivanjem vlastitih fotografija, videosnimaka, fotografija svoje obitelji i sličnog sadržaja gube dio kontrole i dio privatnosti (Forner i sur., 2014).

Ranija istraživanja (Ropelato, 2006; Gross i Acquisti, 2005) upućuju na nisku svijest o sigurnosti i privatnosti, pa tako $29 \%$ sudionika u dobi od 7 do 17 godina i $50.8 \%$ odraslih ima vidljivu kućnu adresu, a $14 \%$ djece ima vidljivu e-mail adresu te $87.8 \%$ odraslih daje telefonski broj. Livingstone i suradnici (2011) utvrdili su kako $43 \%$ korisnika društvenih mreža ima profil u kojem su osobne informacije vidljive samo prijateljima, dok $28 \%$ ima djelomično privatan profil, a čak $26 \%$ djece izvještava o tome kako je njihov profil javan i kako su informacije dostupne svima. Mlađi korisnici Facebooka otkrivaju više osobnih informacija, provode više vremena na toj društvenoj mreži i koriste manje postavki privatnosti (Christofides, Muise i Desmarais, 2012).

U pogledu spolnih razlika, podaci sugeriraju kako muški sudionici pokazuju viši stupanj prekomjerne upotrebe interneta (Üneri i Tanıdır, 2011; Livingstone i sur., 2011; Dufour i sur., 2016). Postoje različiti termini koji opisuju ovakvo ponašanje, kao što su ovisnost o internetu, patološka uporaba interneta i problematična uporaba interneta (Yellowlees i Marks, 2007). Sindrom prekomjerne uporabe interneta (Chou, 2001) odnosi se na prekomjernu količinu vremena provedenu na internetu, kompulzivnu uporabu interneta, poteškoće u upravljanju vremenom provedenim na internetu, osjećaj o tome da je svijet izvan interneta dosadan, osoba postaje razdražena ako se uznemiruje dok je na internetu te smanjenu socijalnu interakciju uživo. Što se tiče vremena provedenog na internetu, Young (1996) navodi kako se kao kriterij ovisnosti o internetu uzima u prosjeku 38 i više sati tjedno na internetu radi zadovoljstva. Međutim u obzir se ne može uzeti samo vrijeme provedeno na internetu nego i drugi kriteriji kao, na primjer da takva uporaba može narušiti obiteljske i bliske odnose s drugima, kao i rad te školovanje. Smatralo se kako je internet tehnološka "igračka" dječaka i mladića (Weiser, 2000), a ranije procjene pokazuju da je od jedne trećine do $40 \%$ korisnika interneta ženskog spola (Morahan-Martin, 1998). Međutim, kako je internet postao najkorišteniji medij, smanjile su se 
i spolne razlike. Tako se dječaci i djevojčice u jednakoj mjeri koriste Internetom. Stariji adolescenti (14 - 17 godina) nešto se više služe internetom nego mlađi (12 - 13 godina; Lenhart, Purcell, Smith, i Zickuhr, 2010). Spolne razlike postoje u aktivnostima u koje se mladi upuštaju na internetu, pri čemu dječake privlači igranje igrica putem interneta, a djevojčice komunikacija putem interneta (Chak i Leung, 2004).

Što se tiče spola, utvrđeno je kako dječaci pristupaju društvenim mrežama u većoj mjeri, a što se s porastom dobi mijenja. Dječaci imaju tendenciju otkrivanja više osobnih podataka na društvenim mrežama nego djevojčice (Fogel i Nehmad, 2009). Djevojke se društvenim mrežama koriste u svrhu dopisivanja s prijateljima iz stvarnog života, za razliku od mladića koji se često dopisuju s nepoznatim osobama na društvenim mrežama (Boyd, 2007). Različita istraživanja pokazuju kako su dječaci više motivirani od djevojčica u pogledu funkcionalnih i zabavnih aktivnosti na internetu, što uključuje pretraživanje web stranica, igranje igrica te preuzimanje filmova i aplikacija (Subrahmanyam, Kraut, Greenfield i Gross, 2001; Lenhart, Madden i Hitlin, 2005; Livingstone i sur., 2011). Nasuprot tome, djevojke se češće koriste internetom za obrazovne i socijalne aktivnosti (Subrahmanyam i sur., 2001), uključujući chat, društvene mreže, $e$ mail i slušanje glazbe (Vlček, 2016). Djevojčice se društvenim mrežama koriste više u svrhu komunikacije s prijateljima (Fairlie, 2016), dok je kod dječaka češće svrha socijalna kompenzacija, učenje i izgradnja socijalnog identiteta te zadovoljstva (Vlček, 2016).

\section{RODITELSKO NADZIRANJE DJECE PRI KORIŠTENJU INTERNETOM}

Prožetost života informacijsko-komunikacijskim tehnologijama (IKT) u posljednjih nekoliko desetljeća, a posebno u zadnjih desetak godina, privukli su veliku pažnju, pa i zabrinutost znanstvenika, stručnjaka, nastavnika i roditelja. Često se ističu rizici pri dječjem korištenju IKT-om, poput nastanka ovisnosti, pretilosti zbog smanjene tjelesne aktivnosti, mržnja, cyberbullying, narušavanje privatnosti te rizici izloženosti pornografskim sadržajima (Nikodem, Kudek Mirošević i Bunjevac Nikodem, 2014). Roditeljsko ponašanje, uključujući roditeljski nadzor, dobilo je posve novo područje djelovanja - usmjeravanje djetetovog ponašanja tijekom korištenja IKT-a. lako su Livingstone i sur. (2011) na temelju dječjih iskaza utvrdili kako 70\% roditelja razgovara s djecom o ponašanju na internetu, ujedno su utvrdili kako $13 \%$ roditelja to nikada ne čini. Kako uključenost roditelja može smanjiti rizik od online zlostavljanja od strane vršnjaka (Ybarra i Mitchell, 2004), važno je da roditelji uistinu nadziru i ova dječja ponašanja. Cole (2001) iznosi podatak kako 55\% djece u dobi od 12 do 15 godina navodi kako ne govori roditeljima o svojim aktivnostima na internetu, no odrasli u velikoj mjeri iskazuju kako nadziru njihovo korištenje interneta (91\%). Pritom je vremensko ograničenje uporabe prisutno kod $62 \%$ djece, korištenje softvera za filtriranje ili blokiranje upitnih web stranica prisutno je kod $32 \%$ djece, dok $67 \%$ djece navodi kako uvijek mora tražiti dopuštenje roditelja za pristup internetu. Roditelji uz vremensko ograničenje često postavljaju i pravila kako bi upravljali djetetovim služenjem internetom. Većina pravila odnosi se na otkrivanje osobnih informacija (85\%), objavljivanje različitih sadržaja (63\%) te na korištenje društvenim mrežama. (47\%), pri čemu $38 \%$ djece navodi kako imaju ograničenja u razmjenjivanju poruka putem interneta (Haddon i Livingstone, 2012).

Roditeljskim nadzorom smatra se skup roditeljskih postupaka ili ponašanja kojim roditelji prate aktivnosti djece i adolescenata (Borawski, levers-Landis, Lovegreen i Trapl, 2003). Tradicionalno, nadzor je jedna od dvije temeljne bipolarne dimenzije roditeljskog stila koja uz emocionalnost/toplinu omogućuje razlikovanje četiri stila roditeljstva: autoritativan, autoritaran, permisivan i ambivalentan (Baumrind, 1971). Roditeljski nadzor iskazuje razinu vođenja pri kojoj oni zabranjuju određena ponašanja na internetu i/ili uspostavljaju pravila, dok se roditeljska toplina može definirati kao razina komunikacije s djecom i podrške koju im daju (Valcke, Bonte, De Wever i Rots, 2010). Livingstone i Haddon (2009) definirali su pet vrsta medijacije 
roditelja u služenju internetom njihove djece: a) aktivno posredovanje (roditelji su prisutni kada se dijete koristi internetom i pomažu mu u tome); b) poticanje djece na sigurno korištenje internetom (roditelji raspravljaju o pravilnom ponašanju prilikom služenja internetom s djecom, pružaju savjete i podučavaju kako se ponašati na internetu); c) uspostavljanje granica ponašanja (roditelji postavljaju pravila i ograničenja); d) praćenje (stalna provjera web stranica koju djeca posjećuju što uključuje praćenje kontakata, poruka i profila na različitim društvenim mrežama) i e) postavljanje tehničkih ograničenja (korištenje posebnog softvera za blokiranje i filtriranje web stranica, praćenje posjećenih web stranica ili postavljanje vremenskog ograničenja). Nadzor može biti postavljen na način da se definira restrikcija upotrebe (koliko se vremena dnevno smije provoditi na računalu) ili razgovorom o sigurnoj upotrebi interneta između roditelja i djece (Smith, Gradisar i King, 2015).

Roditelji koji su motivirani i kompetentni za služenje internetom djeci daju više informacija o korištenju internetom nego roditelji koji djeci to zabranjuju i ne dopuštaju postavljanja pitanja (Huang, 2002). Roditeljsko poznavanje interesa dječjeg služenja internetom upućuje na poboljšana roditeljska iskustva i bolji odnos između djece i roditelja (Kerr, Stattin i Burk, 2010). Roditelji znatno češće zauzimaju aktivnu ulogu u dječjem korištenju interneta ako su djeca mlađe dobi. Navodi se kako 93\% roditelja govori o tome kako poduzimaju neku od strategija medijacije u korištenju interneta njihove djece, ako su djeca u dobnoj skupini od 9 do 10 godina što se s porastom dobi smanjuje (Haddon i Livingstone, 2012).

Prema istraživanju Livingstonove (2007) 95\% roditelja ima pozitivan stav o računalima pri čemu vjeruju kako korištenje interneta pozitivno utječe na akademski uspjeh i postaje dio suvremenog načina života. Roditelji koji imaju ambivalentan stav prema služenju internetom njihove djece slažu se da internet pomaže djeci u vezi sa školom i otkrivanjem novih stvari, no ističu i da krije različite opasnosti, kao što su zlouporaba podataka djece i izlaganje nasilnim i pornografskim sadržajima (Livingstone i Bober, 2004). Studije koje su se bavile roditeljskim pravilima i ograničenjima korištenja interneta pokazale su kako postavljanje strogih pravila s obzirom na količinu vremena provedenog na internetu može promovirati kompulzivnu tendenciju djece pri odnosu korištenja računalom (Eastin, Greenberg, i Hofschire, 2006; van den Eijnden, Spijkerman, Vermulst, van Rooij i Engels, 2010).

Istraživanje koje su proveli Aunola, Stattin i Nurmi (2000) pokazalo je kako se roditelji ponašaju autoritarnije prema kćerima, a permisivnije prema sinovima - roditelji određuju više pravila za kćeri i dosljedniji su u nadzoru djevojčica s obzirom na upotrebu interneta. Roditelji djevojčica češće znaju koje stranice i sadržaje one posjećuju na internetu u odnosu na roditelje dječaka (Haddon i Livingstone, 2012) te roditelji u puno većoj mjeri nadgledaju služenje internetom ženske djece (Meehan i Hickey, 2016).

Stoga se u ovom istraživanju htjelo ispitati obilježja roditeljskog nadzora u odnosu na pitanje nadzora, kontrole, dopuštanja korištenja i podučavanja te razlike u posjedovanju Facebook profila u skupinama djece u dobi 9 do 11 godina, kao i razlike u ponašanjima na internetu između učenika s percipiranim visokim i niskim nadzorom. Ispitivane su i spolne razlike u posjedovanju Facebook profila, u ponašanjima na internetu i razini roditeljskog nadzora (mlađih od 13 godina, tj. mlađih od minimalne dobi za legalno posjedovanje Facebook profila).

\section{Metoda}

\section{Sudionici}

U istraživanju je sudjelovalo 388 učenika (196 dječaka; 49.5\%, 192 djevojčice; 50.5\%) četvrtih razreda osnovnih škola u dobi od 9 do 11 godina pri čemu je prosječna dob sudionika 9.81 godina $(S D=.451)$. 


\section{Instrumenti}

\section{Upitnik sociodemografskih obilježja}

Upitnik sociodemografskih obilježja sadrži pitanja vezana za spol sudionika, dob, vrstu škole, razred, školski uspjeh, obrazovanje roditelja, broj članova u obitelji te osnovne informacije vezane uz korištenje interneta (dostupnost, način pristupanja i količina provedenog vremena na internetu).

Anketni upitnik ponašanja na internetu (Šincek, Tomašić Humer, Duvnjak i Milić, 2015)

Upitnik je osmišljen za potrebe ovoga istraživanja. Ima četiri dijela - prvi dio mjeri količinu vremena koju djeca provode u različitim aktivnostima na internetu ( 7 tvrdnji na koje sudionici odgovaraju na skali od 5 stupnjeva, tj. od "nikad“ do "više od 5 sati“), drugi dio ispituje motive pristupanja internetu ( 6 tvrdnji na kojima sudionici na skali od 3 stupnja (od "nikada" do "često“) označuju koliko ih navedeni razlog motivira), treći dio prati koliko često djeca objavljuju različite sadržaje na društvenim mrežama (11 tvrdnji na kojima sudionici procjenjuju čestinu svog ponašanja na skali od 5 stupnjeva, tj. od "ne koristim društvene mreže“ do "često“) i četvrti dio koji se odnosi na otkrivanje osobnih informacija na Facebooku (8 čestica na koja odgovaraju koliko je pojedina informacija dostupna drugima na skali od 5 stupnjeva, tj. od „Javno, svima“ do „Nemam Facebook“ te je veći rezultat pokazatelj manjeg otkrivanja).

\section{Upitnik roditeljskog nadzora (URK; Šincek, Tomašić Humer, Duvnjak i Milić, 2015)}

Upitnik roditeljskog nadzora ispituje kakvim učenici procjenjuju roditeljski nadzor njihovog ponašanja na internetu. Upitnik se sastoji od 8 tvrdnji na koje sudionici odgovaraju "da“ ako smatraju da njihovi roditelji čine opisano, odnosno "ne" ako misle da to roditelji ne čine (npr. „Roditelji nadgledaju moje korištenje društvenih mreža“) Ukupni rezultat formira se kao aritmetička sredina odgovora sudionika na svim česticama te viši rezultat pokazuje nižu razinu roditeljskog nadzora.

\section{Postupak}

Istraživanje je provedeno u okviru "Safer Internet Centre Croatia: Making the Internet a Good and Safe Place", a financirala ga je Europska Unija. Dobivena su potrebna dopuštenja Etičkoga povjerenstva, ravnatelja škole te informirani pristanak roditelja i djece. Zbog dobi ispitanika tijekom provođenja u svakom su razredu bile dvije psihologinje (zaposlenice na projektu). Nakon ispunjavanja upitnika učenicima se zahvalilo na sudjelovanju te su obaviješteni kome se mogu obratiti ako za tim imaju potrebu ili ako ih je istraživanje uznemirilo.

\section{Rezultati}

U tablici 1. prikazane su aritmetičke sredine i standardne devijacije za korištene varijable. Za navedene varijable prikazani su i teorijski minimum/maksimum te postignuti minimum/ maksimum. 
Tablica 1. Deskriptivni podaci za aspekte ponašanja na internetu i roditeljski nadzor ( $N=388)$

\begin{tabular}{lcccc}
\hline Varijabla & M & SD & Min (Tmin) & Max (TMax) \\
\hline Učestalost radnim danom & 1.89 & 1.971 & $0(0)$ & $12(12)$ \\
Učestalost vikendom & 2.71 & 2.634 & $0(0)$ & $12(12)$ \\
Aktivnosti & 1.98 & 0.583 & $1(1)$ & $4.43(5)$ \\
Motivacija & 1.92 & 0.387 & $1(1)$ & $3(3)$ \\
Objavljivanje sadržaja na & 2.14 & 0.840 & $1(1)$ & $4.55(5)$ \\
društvenim mrežama & & & $1.38(1)$ & $5(5)$ \\
Otkrivanje informacija na Fb & 4.47 & 0.830 & $1(1)$ & $2(2)$ \\
Roditeljski nadzor & 1.46 & 0.211 & & \\
\hline
\end{tabular}

**p<.01 Legenda: M - aritmetička sredina, SD - standardna devijacija, Min - najniži rezultat, Tmin - teorijski najniži rezultat, Max - najviši rezultat, Tmax - teorijski najviši rezultat

Dobiveni deskriptivni rezultati pokazuju kako učenici radnim danom provode gotovo dva sata na internetu, a vikendom u prosjeku gotovo tri sata. Što se tiče vremena koje učenici provode u različitim aktivnostima na internetu (igranje igrica, slušanje glazbe, dopisivanje, itd.), navode kako u prosjeku u svakoj od navedenih aktivnosti provode nešto manje od jednog sata dnevno. Nadalje, što se tiče motivacije za korištenje interneta, navode kako u prosjeku rijetko pristupaju internetu zbog navedenih razloga. Pregledom frekvencija i postotaka rezultata doznaje se da gotovo $32 \%$ učenika navodi kako se često koristi internetom zbog dosade $(47 \%$ rijetko), $55 \%$ ih često i $38 \%$ rijetko pristupa zato što ih nešto zanima, $49 \%$ ih rijetko i $26 \%$ često pristupa internetu zato što treba pronaći neku informaciju za školu, dok ih $25 \%$ nikada to ne čini. Nadalje, 37\% učenika često, a 32\% rijetko pristupa internetu jer se žele družiti, dok ih $31 \%$ nikada to ne čini iz navedenog razloga. Kad govore o tome tko internetu pristupa jer ne može bez njega - $17 \%$ učenika navodi da to radi često, a 19\% učenika navodi da to radi rijetko, dok $6 \%$ često i $16 \%$ rijetko pristupa internetu da ne budu drugačiji od vršnjaka. Što se tiče objavljivanja sadržaja, pokazalo se kako učenici najčešće nikada ne objavljuju ispitivane sadržaje na internetu, dok u manjoj mjeri neke sadržaje objavljuju rijetko (npr. objavljivanje vlastitih slika: $18 \%$ rijetko, $15 \%$ ponekad i $6 \%$ često). Analiza čestica otkrivanja informacija na Facebooku pokazuje kako unatoč dobnoj granici od 13 godina za otvaranje Facebook profila, oko 30\% ispitivanih učenika prosječne dobi od deset godina ima Facebook profil. Međutim, učenici navode kako gotovo nikada ne otkrivaju navedene informacije na Facebooku.

Ispitivanje obilježja roditeljskog nadzora pokazalo je da $62.6 \%$ sudionika navodi kako roditelji ograničavaju njihovo korištenje internetom, $79.4 \%$ navodi kako roditelji ograničavaju služenje i internetom i računalom, 51.3\% sudionika razgovara s roditeljima o sadržaju koji objavljuju, no $54.9 \%$ njih navodi kako roditelji ne nadgledaju njihovo korištenje društvenim mrežama. Pohvalno je da $90.2 \%$ sudionika poštuje pravila roditelja o služenju internetom.

Za provjeru razlikuju li se ponašanja učenika koji percipiraju visok roditeljski nadzor od ponašanja učenika s roditeljima niskog nadzora, metodom ekstremnih skupina (30\% najnižih i $30 \%$ najviših rezultata) formirane su skupina učenika koji percipiraju izrazito nisku $(n=129)$ i skupina učenika koji percipiraju izrazito visoku $(n=104)$ razinu nadzora.

Pomoću hi-kvadrat testa ispitalo se razlikuje li se broj učenika koji posjeduje Facebook profil i ima visok roditeljski nadzor od broja učenika s tim profilom i niskim roditeljskim nadzorom. Rezultati hi-kvadrat testa prikazani su u tablici 2. 
Tablica 2. Rezultati hi-kvadrat testa za odnos broja sudionika s percipiranim visokim i niskim roditeljskim nadzorom, a koji posjeduju ili ne posjeduju Facebook profil $(N=223)$

\begin{tabular}{|c|c|c|c|c|c|}
\hline & & \multicolumn{2}{|c|}{ Posjedovanje Fb profila } & \multirow{3}{*}{$x^{2}$} & \multirow{3}{*}{$\mathbf{p}$} \\
\hline & & Imam & Nemam & & \\
\hline & & $f$ (teor. f) & $f$ (teor. f) & & \\
\hline Roditeljski & Niski & $38(42)$ & $87(83)$ & & \\
\hline nadzor & Visoki & $37(33)$ & $61(65)$ & 1.331 & .249 \\
\hline
\end{tabular}

Legenda: $\mathrm{f}$ - frekvencija, (teor.f) - teorijska frekvencija, $\chi 2$ - Hi-kvadrat, $\mathrm{p}$ - značajnost

Hi-kvadrat nije značajan, dakle podjednak broj učenika s Facebook profilom ima visoki i niski roditeljski nadzor. Isto vrijedi i za sudionike koji nemaju taj profil.

Zatim se t-testom nastojalo ispitati postoje li razlike između ove dvije skupine učenika u učestalosti služenja internetom radnim danom i vikendom, aktivnostima i motivaciji za pristupanje internetu. Rezultati t-testova prikazani su u tablici 3.

Tablica 3. Razlike u učestalosti korištenja internetom, aktivnostima i motivaciji za pristupanje internetu kod sudionika s percipiranim visokim i niskim roditeljskim nadzorom $(N=233)$

\begin{tabular}{|c|c|c|c|c|c|c|}
\hline \multirow[b]{2}{*}{ Varijabla } & \multicolumn{2}{|c|}{ Niski } & \multicolumn{2}{|c|}{ Visoki } & \multirow[b]{2}{*}{$\mathbf{t}$} & \multirow[b]{2}{*}{$\mathbf{p}$} \\
\hline & $\mathbf{M}$ & SD & $\mathbf{M}$ & SD & & \\
\hline Učestalost radnim danom & 1.90 & 2.172 & 1.85 & 1.628 & -.192 & .848 \\
\hline Učestalost vikendom & 2.71 & 2.795 & 2.67 & 2.513 & -.108 & .914 \\
\hline \multicolumn{7}{|l|}{ Aktivnosti } \\
\hline Igranje igrica & 2.57 & .905 & 2.50 & .906 & -.517 & .606 \\
\hline Slušanje glazbe & 2.31 & .925 & 2.39 & .807 & .687 & .492 \\
\hline Dopisivanje & 1.97 & 1.023 & 2.37 & .922 & 3.147 & $.002 *$ \\
\hline Objavljivanje postova & 1.39 & .713 & 1.45 & .655 & .657 & .512 \\
\hline Praćenje grupa & 1.59 & .992 & 1.75 & .861 & 1.311 & .191 \\
\hline Traženje pod. (potrebni) & 1.76 & .929 & 1.97 & .906 & 1.750 & .082 \\
\hline Traženje pod. (zanimljivi) & 1.72 & .875 & 2.03 & 1.004 & 2.457 & $.015^{*}$ \\
\hline \multicolumn{7}{|l|}{ Motivacija } \\
\hline Dosada & 2.14 & .784 & 2.14 & .703 & .026 & .980 \\
\hline Traženje zanimljivosti & 2.48 & .652 & 2.53 & .590 & .640 & .523 \\
\hline Traženje informacija & 1.89 & .707 & 2.18 & .713 & 3.051 & $.003^{*}$ \\
\hline Želja za druženjem & 1.98 & .867 & 2.26 & .796 & 2.471 & $.014^{*}$ \\
\hline Pristup jer ne može bez interneta & 1.56 & .861 & 1.47 & .683 & -.914 & .362 \\
\hline $\begin{array}{l}\text { Pristup da ne bude drugačiji od } \\
\text { drugih }\end{array}$ & 1.25 & .550 & 1.26 & .549 & -.187 & .852 \\
\hline
\end{tabular}

*p<.05 Legenda: M - aritmetička sredina, SD - standardna devijacija, t - t-test, $\mathrm{p}$ - značajnost

Sudionici koji percipiraju visoku razinu roditeljskog nadzora provode više vremena dnevno u dopisivanju s prijateljima i u traženju podataka koji su im zanimljivi nego što to čine sudionici koji percipiraju nisku razinu nadzora.

Sudionici koji percipiraju visoku razinu nadzora češće pronalaze motivaciju za pristupanje internetu u traženju informacija vezanih za školu od sudionika s niskom razinom nadzora. Nadalje, sudionici s visokom razinom nadzora više su motivirani željom za druženjem kao razlogom za korištenje internetom od sudionika s niskom razinom nadzora. 
Nadalje, ispitane su razlike u objavljivanju sadržaja i otkrivanju osobnih informacija sudionika s percipiranim visokim i niskim roditeljskim nadzorom, a rezultati t-testova prikazani su u tablici 4.

Tablica 4. Razlika u objavljivanju sadržaja na društvenim mrežama i otkrivanju osobnih informacija na Facebooku sudionika s percipiranim visokim i niskim roditeljskim nadzorom

\begin{tabular}{|c|c|c|c|c|c|c|}
\hline \multirow[b]{3}{*}{ Varijabla } & \multicolumn{2}{|c|}{ Niski } & \multicolumn{2}{|c|}{ Visoki } & \multirow[b]{3}{*}{$\mathbf{t}$} & \multirow[b]{3}{*}{$\mathbf{p}$} \\
\hline & \multicolumn{2}{|c|}{54} & \multicolumn{2}{|c|}{72} & & \\
\hline & $\mathbf{M}$ & SD & $\mathbf{M}$ & SD & & \\
\hline \multicolumn{7}{|l|}{ Objavljivanje sadržaja } \\
\hline Slike sebe & 2.89 & 1.003 & 3.03 & .964 & .782 & .436 \\
\hline Slike obitelji & 2.37 & .734 & 2.85 & .974 & 3.133 & $.002^{*}$ \\
\hline Slike prijatelja & 2.70 & .944 & 2.81 & .850 & .625 & .533 \\
\hline Statusi o sebi & 2.41 & .765 & 2.46 & .821 & .358 & .721 \\
\hline Statusi o drugima & 2.17 & .505 & 2.38 & .740 & 1.877 & .063 \\
\hline Statusi sa citatima & 2.24 & .581 & 2.51 & .888 & 2.083 & $.039 *$ \\
\hline Statuse s lokacijama & 2.19 & .479 & 2.35 & .695 & 1.548 & .124 \\
\hline Linkovi pjesama & 3.06 & 1.140 & 2.88 & 1.113 & -.889 & .376 \\
\hline Poučni sadržaji & 2.61 & .878 & 2.74 & 1.007 & .742 & .459 \\
\hline Zanimljivi clipovi & 3.17 & 1.145 & 3.00 & 1.163 & -.803 & .424 \\
\hline Linkovi na Ask.fm & 2.20 & .626 & 2.22 & .587 & .169 & .866 \\
\hline$n$ & \multicolumn{2}{|c|}{36} & \multicolumn{2}{|c|}{38} & & \\
\hline \multicolumn{7}{|l|}{ Otkrivanje informacija } \\
\hline Spol & 3.32 & 1.068 & 3.36 & 1.046 & .184 & .854 \\
\hline Datum rođenja & 3.45 & .950 & 3.03 & 1.134 & -1.721 & .090 \\
\hline Kućna adresa & 3.82 & .609 & 3.61 & .728 & -1.308 & .195 \\
\hline Ime škole & 3.39 & .974 & 3.17 & 1.000 & -.993 & .324 \\
\hline Status veze & 3.84 & .594 & 3.64 & .931 & -1.113 & .270 \\
\hline Broj telefona i mobitela & 3.63 & .675 & 3.39 & .934 & -1.275 & .207 \\
\hline E-mail adresa & 3.76 & .675 & 3.61 & .871 & -.836 & .406 \\
\hline Religijsko opredjeljenje & 3.82 & .609 & 3.44 & 1.027 & -1.880 & .065 \\
\hline
\end{tabular}

* p <.05 Legenda: M - aritmetička sredina, SD - standardna devijacija, t - t-test, $\mathrm{p}$ - značajnost

Ispitano je razlikuju li se učenici s percipiranim visokim i oni s percipiranim niskim roditeljskim nadzorom u objavljivanju sadržaja na društvenim mrežama i otkrivanju osobnih informacija na Facebooku, pri čemu su iz obrade isključeni sudionici koji se ne koriste društvenim mrežama i Facebookom. Stoga je obrada za objavljivanje sadržaja na društvenim mrežama provedena na 126 sudionika koji se koriste društvenim mrežama, a za otkrivanje osobnih podataka na Facebooku na 74 sudionika koji se koriste Facebookom. Rezultati su prikazani u tablici 4.

Sudionici, koji percipiraju visoku razinu nadzora, objavljuju češće slike obitelji od sudionika koji percipiraju nisku razinu nadzora. Isto tako, sudionici koji percipiraju visoku razinu nadzora $(M=2.51, S D=.888)$ objavljuju češće statuse koji sadrže citate od sudionika s niskom razinom nadzora.

Također su ispitane i spolne razlike u posjedovanju Facebook profila. Tablica 5 prikazuje rezultate hi-kvadrat testa za spolne razlike. 
Tablica 5. Rezultati hi-kvadrat testa za frekvencije spola s obzirom na posjedovanje Facebook profila $(N=368)$

\begin{tabular}{|c|c|c|c|c|c|}
\hline & & \multicolumn{2}{|c|}{ Posjedovanje Fb profila } & \multirow{3}{*}{$x^{2}$} & \multirow{3}{*}{$\mathbf{p}$} \\
\hline & & Imam & Nemam & & \\
\hline & & $f$ (teor. f) & $f$ (teor. f) & & \\
\hline \multirow[t]{2}{*}{ Spol } & Dječaci & $72(62.2)$ & $111(120.8)$ & & \\
\hline & Djevojčice & $53(62.8)$ & $132(122.8)$ & 4.692 & $.030^{*}$ \\
\hline
\end{tabular}

${ }^{*} p<.05$ Legenda: $f$ - frekvencija, (teor.f) - teorijska frekvencija, $\chi 2$ - Hi-kvadrat, $p$ - značajnost

Hi kvadrat pokazuje da kod dječaka više njih nego što se očekuje po teorijskim frekvencijama ima Facebook profil, dok kod djevojčica manje njih nego što se očekuje po teorijskim frekvencijama ima isti profil.

Također se nastojalo odgovoriti na pitanje postoje li spolne razlike u učestalosti korištenja internetom radnim danom i vikendom, aktivnostima, motivaciji za pristupanje internetu i roditeljskom nadzoru. Rezultati t-testova prikazani su u tablici 6.

Tablica 6 Spolne razlike u učestalosti korištenja internetom radnim danom i vikendom, aktivnostima, motivaciji za pristupanje internetu i roditeljskom nadzoru $(N=388)$

\begin{tabular}{|c|c|c|c|c|c|c|}
\hline & \multicolumn{2}{|c|}{ Dječaci } & \multicolumn{2}{|c|}{ Djevojčice } & \multirow[b]{2}{*}{$\mathbf{t}$} & \multirow[b]{2}{*}{$p$} \\
\hline Varijabla & $\mathbf{M}$ & SD & $\mathbf{M}$ & SD & & \\
\hline Učestalost radnim danom & 2.25 & 2.139 & 1.55 & 1.731 & 3.507 & $.001^{*}$ \\
\hline Učestalost vikendom & 3.55 & 2.967 & 1.94 & 2.005 & 6.803 & $.000^{*}$ \\
\hline \multicolumn{7}{|l|}{ Aktivnosti } \\
\hline Igranje igrica & 2.85 & .967 & 2.24 & .760 & 6.809 & $.000^{*}$ \\
\hline Slušanje glazbe & 2.27 & .950 & 2.43 & .818 & -1.813 & .071 \\
\hline Dopisivanje s prijateljima & 2.15 & 1.021 & 2.20 & .891 & -.557 & .578 \\
\hline Objavljivanje postova & 1.52 & .771 & 1.33 & .662 & 2.658 & $.008^{*}$ \\
\hline Praćenje grupa & 1.86 & 1.078 & 1.51 & .750 & 3.725 & $.000 *$ \\
\hline Traženje pod. (potrebni) & 1.85 & .994 & 1.89 & .899 & -.418 & .676 \\
\hline Traženje pod. (zanimljivi) & 2.03 & 1.133 & 1.69 & .860 & 3.307 & $.001^{*}$ \\
\hline \multicolumn{7}{|l|}{ Motivacija } \\
\hline Dosada & 2.21 & .761 & 2.03 & .690 & 2.499 & $.013^{*}$ \\
\hline Traženje zanimljivosti & 2.51 & .649 & 2.51 & .595 & .003 & .998 \\
\hline Traženje informacija & 1.92 & .695 & 2.14 & .711 & -2.987 & $.003^{*}$ \\
\hline Želja za druženjem & 2.12 & .837 & 2.00 & .810 & 1.455 & .146 \\
\hline $\begin{array}{l}\text { Pristup jer ne može bez } \\
\text { interneta }\end{array}$ & 1.67 & .857 & 1.42 & .702 & 3.075 & $.002^{*}$ \\
\hline $\begin{array}{l}\text { Pristup da ne bude drugačiji } \\
\text { od drugih }\end{array}$ & 1.37 & .653 & 1.21 & .489 & 2.714 & $.007^{*}$ \\
\hline Roditeljski nadzor & 1.48 & .211 & 1.44 & .209 & 1.696 & .091 \\
\hline
\end{tabular}

*p<.05 Legenda: M - aritmetička sredina, SD - standardna devijacija, t - t-test, $\mathrm{p}$ - značajnost

Dječaci provode više vremena na internetu radnim danom i vikendom nego što to čine djevojčice.

U pogledu aktivnosti na internetu pokazalo se da dječaci provode više vremena dnevno u igranju igrica nego što to čine djevojčice. Dječaci također češće objavljuju postove nego djevojčice. Isto tako, dječaci češće prate grupe nego što to čine djevojčice. Razlike su se pokazale 
značajnima i u traženju podataka koji su zanimljivi, pri čemu dječaci provode više vremena dnevno u toj aktivnosti nego djevojčice.

Dječaci češće pristupaju internetu motivirani otklanjanjem dosade u odnosu na djevojčice. Djevojčice češće pristupaju internetu zbog traženja informacija potrebnih za školu nego što to čine dječaci. Dječaci češće, u usporedbi s djevojčicama, pristupaju internetu jer ne mogu bez njega. Osim toga, dječaci češće pristupaju internetu iz želje da ne budu drugačiji od drugih nego što to čine djevojčice.

U percipiranoj razini roditeljskog nadzora nije utvrđena statistički značajna razlika između dječaka i djevojčica što upućuje na to da se dječaci i djevojčice ne razlikuju po percepciji roditeljskog nadzora. Pri ispitivanju razlika između dječaka i djevojčica u objavljivanju sadržaja na društvenim mrežama i otkrivanju osobnih informacija na Facebooku iz obrade su isključeni sudionici koji se ne koriste društvenim mrežama i Facebookom. Stoga je prvi niz obrada proveden na 195 sudionika koji se koriste raznim društvenim mrežama, a drugi na 121 sudioniku koji se koristi Facebookom. Rezultati su prikazani u tablici 7.

Tablica 7. Spolne razlike u objavljivanju sadržaja na društvenim mrežama i otkrivanju osobnih informacija na Facebooku

\begin{tabular}{|c|c|c|c|c|c|c|}
\hline & \multicolumn{2}{|c|}{ Dječaci } & \multicolumn{2}{|c|}{ Djevojčice } & \multirow[b]{3}{*}{$\mathbf{t}$} & \multirow[b]{3}{*}{$\mathbf{p}$} \\
\hline \multirow[b]{2}{*}{ Varijabla } & \multicolumn{2}{|c|}{96} & \multicolumn{2}{|c|}{99} & & \\
\hline & M & SD & M & SD & & \\
\hline \multicolumn{7}{|l|}{ Objavljivanje sadržaja } \\
\hline Svoje slike & 2.88 & .886 & 2.97 & 1.035 & -.687 & .493 \\
\hline Slike obitelji & 2.65 & .894 & 2.55 & .848 & .804 & .423 \\
\hline Slike prijatelja & 2.80 & 1.001 & 2.75 & .907 & .399 & .691 \\
\hline Statusi o sebi & 2.53 & .833 & 2.23 & .603 & 2.863 & $.005^{*}$ \\
\hline Statusi o drugima & 2.42 & .735 & 2.21 & .611 & 2.110 & $.036 *$ \\
\hline Statusi sa citatima & 2.43 & .791 & 2.31 & .680 & 1.077 & .283 \\
\hline Statusi s lokacijama & 2.39 & .731 & 2.21 & .558 & 1.857 & .065 \\
\hline Linkovi pjesama & 3.35 & 1.240 & 2.67 & .990 & 4.272 & $.000^{*}$ \\
\hline Poučni sadržaji & 2.97 & 1.119 & 2.53 & .873 & 3.082 & $.000^{*}$ \\
\hline Zanimljivi clipovi & 3.48 & 1.240 & 2.74 & 1.036 & 4.527 & $.000^{*}$ \\
\hline Linkovi na Ask.fm & 2.26 & .714 & 2.14 & .474 & 1.366 & .174 \\
\hline $\mathbf{N}$ & \multicolumn{2}{|c|}{71} & \multicolumn{2}{|c|}{50} & & \\
\hline \multicolumn{7}{|l|}{ Otkrivanje informacija } \\
\hline Spol & 3.17 & 1.095 & 3.44 & 1.033 & -1.386 & .169 \\
\hline Datum rođenja & 3.13 & 1.120 & 3.06 & 1.058 & .334 & .739 \\
\hline Kućna adresa & 3.51 & .860 & 3.76 & .555 & -1.964 & .052 \\
\hline Ime škole & 3.10 & 1.058 & 3.34 & .939 & -1.321 & .189 \\
\hline Status veze & 3.52 & .998 & 3.72 & .640 & -1.334 & .185 \\
\hline Broj telefona & 3.37 & .930 & 3.62 & .635 & -1.784 & .077 \\
\hline E-mail adresa & 3.54 & .923 & 3.78 & .648 & -1.714 & .089 \\
\hline Religijsko opredjeljenje & 3.45 & .968 & 3.78 & .648 & -2.241 & $.027^{*}$ \\
\hline
\end{tabular}

* $\mathrm{p}<.05$ Legenda: $\mathrm{M}$ - aritmetička sredina, SD - standardna devijacija, $\mathrm{t}$ - t-test, $\mathrm{p}$ - značajnost

Pri usporedbi čestine objavljivanja sadržaja na društvenim mrežama dječaci češće objavljuju statuse o sebi i statuse o drugima, linkove pjesama, poučne sadržaje i zanimljive klipove (clip) u odnosu na djevojčice.

U pogledu otkrivanja osobnih informacija na Facebooku viši rezultat označava niže otkrivanje, odnosno manje dostupnih osobnih informacija na Facebooku. Dječaci imaju uglavnom 
dostupne informacije o religijskom opredjeljenju samo nekim prijateljima, dok djevojčice taj tip informacija nikada ne objavljuju na Facebooku.

\section{RASPRAVA}

Cilj ovoga istraživanja bio je ispitati obilježja roditeljskog nadzora i razlike u ponašanju na internetu između skupina s percipiranim visokim i niskim roditeljskim nadzorom te spolne razlike.

U ovom istraživanju veći udio djece roditeljski nadzor percipira visokim, odnosno navode kako roditelji nadziru njihovo služenje internetom, dok Puharić i sur. (2014) navode kako velika većina djece slobodno pristupa svim dostupnim sadržajima na internetu, a Soldatova i Rasskazova (2016) ukazuju kako $14 \%$ djece navodi kako bi voljeli da njihovi roditelji provode aktivniju ulogu u njihovom služenju internetom, s čime se slažu i nalazi Lenhart, Madden, Smith, Purcell, Zickuhr i Rainie (2011). Budući da su djeca mlađe dobne skupine, kojoj pripadaju i sudionici u ovom istraživanju, sklonija imati otvorene profile na društvenim mrežama pri čemu ih četvrtina ima u potpunosti javan profil (Livingstone i sur., 2011), važno je roditelje poticati na veću intervenciju prilikom dječjeg služenja internetom. Sudionici u ovom istraživanju najčešće se ne koriste Facebookom te stoga nemaju otvorene profile, a ako se koriste, najčešće iskazuju kako nikada ne objavljuju osobne informacije na njemu, što je ohrabrujuće u odnosu na prethodna istraživanja, pod uvjetom da nije samo do načina prikupljanja podataka već da upućuje na učinke preventivnih aktivnosti. Djecu treba poticati na sigurno korištenje internetom. Međutim, roditeljima koji su se kasnije upoznali s tehnologijom, nije lako nadzirati upotrebu interneta jer im nedostaje vještina njegove uporabe. Upravo iz tih razloga potrebno je i nadalje usmjeravati roditelje da sa svojom djecom razgovaraju o opasnostima interneta, o sadržajima koje na internetu objavljuju te bi trebali dogovoriti zajedno s djecom vremenski okvir služenja računalom i pristupanja internetu, kao i postaviti pravila kojih će se dosljedno pridržavati. Osim što na taj način prate aktivnosti svoje djece, također ostvaruju i bolje odnose budući da se trude biti uključeni u njihov virtualni život. Istraživanja potvrđuju da je roditeljsko praćenje dosljedno povezano s manje rizičnih ponašanja djece na internetu i neefikasnom upotrebom medija (Bleakley, Ellithorpe, i Romer, 2016).

Pri usporedbi broja sudionika koji posjeduju i ne posjeduju Facebook profil u skupinama s percipiranim visokim, odnosno niskim roditeljskim nadzorom, pokazalo se da podjednak broj sudionika s visokim i niskim roditeljskim nadzorom ima Facebook profil. Ove skupine sudionika uspoređene su s obzirom na različita ponašanja na internetu. Razlike se nisu pokazale značajnima u varijablama koje ispituju učestalost korištenja internetom, što upućuje na to kako se djeca, bez obzira na razinu roditeljskog nadzora, podjednako često služe internetom radnim danom i vikendom. Djeca koja percipiraju visoku razinu roditeljskog nadzora provode više vremena dnevno u dopisivanju s prijateljima i u traženju zanimljivih informacija, češće odlaze na internet zbog traženja informacija vezanih za školu i zbog želje za druženjem. Navedeno se može objasniti time kako ih roditelji češće potiču da se koriste internetom u obrazovne svrhe te im ukazuju na pozitivne strane interneta, kao što je druženje s prijateljima. Moguće je da sudjeluju u aktivnostima zajedno s djecom i njeguju stil povjerenja tako da su djeca razvila obrasce služenja internetom u informativne i komunikacijske svrhe.

Više dječaka nego djevojčica u ovom istraživanju navodi kako imaju Facebook. Ispitivane su spolne razlike u različitim ponašanjima djece na internetu i u percipiranoj razini roditeljskog nadzora. Rezultati upućuju na postojanje razlika u provođenju vremena na internetu radnim danom i vikendom, pri čemu dječaci provode više vremena za računalom u oba slučaja, što se slaže s nalazima istraživanja Grossa (2004). Navedeno se može objasniti time što djevojčice provode slobodno vrijeme češće u krugu obitelji i prijatelja, dok dječaci češće koriste internetske aktivnosti i češće provode vrijeme na otvorenom (Chien-Hsin i sur., 2009). Dječaci češće 
igraju igrice, objavljuju postove, prate grupe i traže podatke koji su im zanimljivi. Također, češće pronalaze motivaciju za pristup internetu u izbjegavanju dosade, želji da ne budu drugačiji od drugih te češće izražavaju kako pristupaju internetu jer ne mogu bez njega, dok djevojčice češće odlaze na internet zbog traženja informacija vezanih za školu. Nalazi su u skladu s pretpostavkom kako dječaci to čine u svrhu socijalne kompenzacije i izgradnje socijalnog identiteta, što je potvrdilo i istraživanje koje je provela Vlček (2016). Također, slažu se s pretpostavkom kako dječaci provode više vremena na internetu i radnim danom i vikendom nego djevojčice te kako su češće usmjereni na zabavu u korištenju internetom, dok su djevojčice usmjerenije na obrazovne svrhe što su potvrdila i druga istraživanja (DeBell i Chapman, 2006; Horzum i Bektaš, 2014).

Nadalje, dječaci češće od djevojčica objavljuju statuse o sebi i statuse o drugima, kao i linkove pjesama te poučne i zanimljive sadržaje, što je iznenađujuće, budući da se pretpostavljalo kako se djevojčice češće koriste socijalnim mrežama za društveno povezivanje i postavljanje fotografija što su pokazali Lenhart i suradnici (2011) u svom istraživanju. Zatim, dječaci imaju dostupne osobne informacije na Facebooku, kao što je religijsko opredjeljenje, uglavnom nekim prijateljima, dok djevojčice navode kako nikada ne objavljuju takvu vrstu informacija. Navedeno se slaže s početnom pretpostavkom ovog istraživanja kako su djevojčice opreznije i kako je manje vjerojatno da će dijeliti na internetu informacije koje ih izravno identificiraju. Rezultati se slažu s rezultatima Special i Li-Barbera (2012) koji navode kako muški korisnici otkrivaju više osobnih informacija na Facebooku. Nalazi se mogu objasniti time što društvene mreže omogućavaju predstavljanje osoba onakvima kakve žele da ih drugi vide, a to utječe i na razvoj slike o sebi, jer je psihološki portret koji oslikavamo o sebi utemeljen djelomično na onome što netko misli o tome kako ga drugi vide (Grgić, 2015), a istraživanja su pokazala kako su dječaci skloniji konformiranju (Salamon, 2007). Budući da su djevojčice po prirodi više socijalno otvorene i društvene u stvarnom svijetu, dječaci nastoje u virtualnom svijetu izgraditi svoj socijalni identitet.

Konačno, djevojčice i dječaci se ne razlikuju u percipiranom roditeljskom nadzoru. Dobiveni rezultati slažu se s nalazima Valcke i suradnika (2010) koji nisu utvrdili razliku u roditeljskom nadzoru kod dječaka i djevojčica. Međutim, rezultati nisu u skladu s drugim istraživanjima koja navode kako djevojčice izražavaju veću uključenost svojih roditelja nego dječaci (UNICEF, 2008; Puharić i sur., 2014; Meehan i Hickey, 2016). Može se zaključiti kako roditelji nisu dovoljno upućeni u opasnosti koje služenje internetom predstavlja za njihovu djecu, bez obzira na spol. Također, moguće je da spolne razlike u razini roditeljskog nadzora nisu vidljive i zbog same dobi sudionika, budući da roditelji češće nadgledaju kćeri u tinejdžerskoj dobi, jer smatraju da su tada podložnije opasnostima interneta.

Ograničenja ovog istraživanja sastoje se u skali roditeljskog nadzora - bilo bi dobro u budućim istraživanjima pratiti različite aspekte kontrole i jasno razdvojiti psihološku i bihevioralnu kontrolu ili pratiti neke specifične oblike roditeljske medijacije. Bilo bi poželjno koristiti se i podacima iz drugih izvora, a ne samo od učenika zbog poznatih izazova samoprocjene u pogledu socijalne poželjnosti odgovora. Važno je imati na umu da je ovo istraživanje zahtijevalo aktivni roditeljski pristanak, a moguće je da su roditelji koji sebe ili svoju djecu doživljavaju rizičnijima, uskratili suglasnost za sudjelovanje.

Bilo bi poželjno u buduća istraživanja uključiti i roditelje sudionika kako bi se provjerila razlika među njima u procjenjivanju roditeljskog nadzora, razina obrazovanja roditelja koja može utjecati na stupanj roditeljskog nadzora te bi se mogli ispitati roditeljski internetski stilovi, budući da su oni povezani s internetskim iskustvom, pristupom internetu i dječjim služenjem internetom. 


\section{ZAKLUČAK}

U našem se istraživanju pokazalo kako su učenici koji roditeljski nadzor percipiraju višim, rizičnijeg ponašanja na internetu, što je iznenađujući nalaz. Moguće je da je viši nadzor posljedica veće sklonosti rizičnom ponašanju na internetu iako se ne može odbaciti mogućnost da pretjerana kontrola rezultira rizičnijim ponašanjem tako visoko kontrolirane djece. Dječaci su očekivano skloniji rizičnijim ponašanjima nego djevojčice. Sa zadovoljstvom se može zaključiti kako djeca smatraju da su roditelji uključeni i nadziru njihova ponašanja na internetu, a sama djeca općenito uglavnom su nerizičnog ponašanja u ovom uzorku. Ipak četvrtina učenika u dobi od 9 do 11 godina navodi da se koristi Facebookom, iako to sukladno pravilima, smiju tek od 13-e godine. S obzirom na dobivene rezultate ovog istraživanja potrebno je osmisliti prevencijske i intervencijske programe kojima bi se educiralo roditelje o opasnostima koje krije internet. Time bi se omogućilo roditeljima da budu više uključeni u život svoje djece, što bi u konačnici rezultiralo boljim poznavanjem djece, a i boljim odnosima unutar obitelji.

Kako bi se omogućio nadzor nad dječjim služenjem internetom, obiteljima je podjednako potrebno tehnološko znanje i roditeljske vještine, kao što su otvorena komunikacija s djecom i konstruktivne povratne informacije. Preporuke za unapređenje sigurnosti djece na internetu jesu učestaliji razgovori, služenje internetom zajedno s djecom, upoznavanje djece s načinima nošenja s potencijalnim rizicima, iskazivanje povjerenja djetetu, spremnost na konstruktivno rješavanje problema te pribavljanje sredstava kojima će se omogućiti lakši nadzor ponašanja djece na internetu.

\section{LITERATURA}

Aunola, K., Stattin, H. K., i Nurmi, J. (2000). Parenting styles and adolescents' achievement strategies. Journal of Adolescence, 23, 205-222.

Baumrind, D. (1971). Effects of authoritative parental control on child behavior. Child Development, 887-907.

Bleakley, A., Ellithorpe, M., i Romer, D. (2016). The Role of Parents in Problematic Internet Use among US Adolescents. Media and Comunication, 4(3), 24-34.

Borawski, E.A., levers-Landis, C.E., Lovegreen, L.D., i Trapl, E.S. (2003). Parental monitoring, negotiated unsupervised time, and parental trust: The role of perceived parenting practices in adolescent health risk behaviors. Journal of Adolescent Health, 33(2), 60-70.

Boyd, D. (2007). Why Youth Heart Social Network Sites: The Role of Networked Publics in Teenage Social Life. The Berkman Center for Internet \& Society Researchat Harvard University, 16, 119142.

Chak, K., i Leung, L. (2004). Shyness and locus of control as predictors of internet addiction and internet use. CyberPsychology \& Behavior, 7(5), 559-570.

Chien-Hsin, L., Shong-Lin, L., i Chin-Pi, W. (2009). The Effects of Parental Monitoring and Leisure Boredom on Adolescents' Internet Addiction. Adolescence, 44, 993-1004.

Chou, C. (2001). Internet heavy use and addiction among Taiwanese college students: an online intervju study. Cyberpsychology and Behavior, 4(5), 573-585.

Christofides, E., Muise, A., i Desmarais, S. (2012). Hey Mom, what's on your Facebook? Comparing Facebook disclosure and privacy in adolescents and adults. Social Psychological and Personality Science, 3(1), 48-54.

Cole, J. (2001). The UCLA Internet Report: Surveying the Digital Future Year 2. CA:UCLA Center for Communication Policy. Preuzeto 16.02.2017. s: http://www.digitalcenter.org/pdf/ InternetReportYearTwo.pdf. 
DeBell, M., i Chapman, C. (2006). Computer and Internet Use by Students in 2003. Statistical Analysis Report. National Center for Education Statistics.

Dufour, M., Brunelle, N., Tremblay, J., Leclerc, D., Cousineau, M., M., Khazaal, Y., Legare, A., A., Rousseau, M., i Berbiche, D. (2016). Gender difference in Internet use and Internet problems among Quebec high school students. The Canadian Journal of Psychiatry, 1-6.

Eastin, M. S., Greenberg, B. S., i Hofschire, L. (2006). Parenting the internet. Journal of Communication, 56, 486-504.

Fairlie, R.W. (2016). Do Boys and Girls Use Computers Differently, and Does It Contribute to Why Boys do Worse in School Than Girls?. J. Econ. Anal. Policy, 16(1), 59-96.

Fogel, J., i Nehmad, E. (2009). Internet social network communities: Risk taking, trust, and privacy concerns. Computers in Human Behavior, 25, 153-160.

Forner, H., Halilčević, S., Ivašković, T., Janjušević, A., Janjušević, D., Kanjir, S., Katanić, M., Martinovsky, S., Poslon, H.I., i Špuren, F. (2014). Sigurno korištenje interneta i Facebooka. Zagreb: Udruga za samozastupanje.

Grgić, I. (2015). Efekt online dezinhibicije - na primjeru Facebooka. Završni rad. Osijek: Odsjek za psihologiju Filozofskog fakulteta u Osijeku.

Gross, E.F. (2004). Adolescent Internet use: What we expect, what teens report. Applied Developmental Psychology, 25, 633-649.

Gross, R., i Acquisti, A. (2005). Information revelation and privacy in online social networks. Proceedings of the 2005 ACM workshop on Privacy in the electronic society. New York, NY: ACM, 7081.

Gross, E.F., Juvonen, J., i Gable, S.L. (2002). Internet Use and Well-Being in Adolescence. Journal of Social Issues, 58(1), 75-90.

Haddon, L., i Livingstone, S. (2012). EU Kids Online II: Enhancing Knowledge Regarding Europen Children's Use, Risk and Safety Online EU Kids Online, Deliverable D1.6. (LSE, London: EU Kids online.

Horzum, M.B., i Bektaš, M. (2014). Examing the Internet Use Aim and Internet Parental Style of Primary School Students in Terms of Various Variables. Croatian Journal of Education, 16(3), 745778.

Huang, Y.P. (2002). A study on the network literacy and network usage of elementary school students. Taiwan: University of Tainan: Master's thesis.

Kerr, M., Stattin, H., i Burk, W.J. (2010). A reinterpretation of parental monitoring in longitudinal perspective. Journal of Research on Adolescence, 20(1), 39-64.

Lenhart, A., Madden, M., i Hitlin P. (2005). Youth are leading the transition to a fully wired and mobile nation. Pew internet \& American Life Project. Washington, D.C.

Lenhart, S., Madden, M., Smith, A., Purcell, K., Zickuhr, K., i Rainie, L. (2011). Teens, Kindness and Cruelty on Social Network Sites. Pew Research Center's Internet \& American Life Project. Washington, D.C.

Lenhart, A., Purcell, K., Smith, A., i Zickuhr, K. (2010). Social Media \& Mobile Internet Use among Teens and Young Adults. Millennials. Pew internet \& American life project.

Livingstone, S. (2007). Strategies of Parental Regulation in the Media-rich Home. Computers in Human Behavior, 23, 920-941.

Livingstone, S., i Bober, M. (2004). UK Children Go Online: Surveying the experiences of young people and their parents.

Livingstone, S., i Haddon, L. (2009). EU Kids Online. Zeitschrift Für Psychologie/Journal of Psychology, 217(4), 236.

Livingstone, S., Haddon, L., Görzig, A., i Ólafsson, K. (2011). Risks and safety on the internet: the perspective of European children: full findings and policy implications from the EU Kids Online survey of 9-16 year olds and their parents in 25 countries. EU Kids Online, Deliverable D4. EU Kids Online Network, London, UK.

Morahan-Martin, J. (1998). The gender gap in Internet use: Why men use the Internet more than women-a literature review. CyberPsychology \& Behavior, 1(1), 3-10. 
Meehan, S., i Hickey, J. (2016). The Experiences of Irish Parents in the Mediation of Their Children's Use of Internet Connected Devices. Journal of Psychology and Clinical Psychiatry, 5(2).

Nikodem, K., Kudek Mirošević, J., i Bunjevac Nikodem, S. (2014). Internet i svakodnevne obaveze djece. Soc. ekol. Zagreb, 23(3), 211-235.

Puharić, Z., Stašević, I., Ropac, D., Petričević, N., i Jurišić, I. (2014). Istraživanje čimbenika nastanka ovisnosti o internetu. Acta Med Croatica, 68, 361-373.

Robotić, P. (2015). Zamke virtualnog svijeta: zaštita djece i mladih na Internetu i prevencija ovisnosti. JAHS, 1(2), 81-96.

Ropelato, J. (2006). Internet Pornography Statistics. Preuzeto 15.09.2017. s: http://www.internetfilter-review.toptenreviews.com/internet-pornography-statistics.html.

Salamon, M. (2007). Povezanost roditeljskog ponašanja, lokusa kontrole kod adolescenata i njihove podložnosti vršnjačkom utjecaju. Diplomski rad. Zagreb: Odsjek za psihologiju Filozofskog fakulteta u Zagrebu.

Smith, L.J., Gradisar, M., i King, D.L. (2015): Parental Influences on Adolescent Video Game Play: A Study of Accessibility, Rules, Limit Setting,Monitoring, and Cybersafety. Cyberpsychology, behavior and social networking, 18(5), 1-7.

Soldatova, G.U., i Rasskazova, E.I. (2016). Adolescent Safety on the Internet. Russian Education \& Society, 58(2), 133-62.

Special, W.P., i Li-Barber, K.T. (2012). Self-disclosure and student satisfaction with Facebook. Computers in Human Behavior, 28(2), 624-630.

Subrahmanyam, K., Kraut, R., Greenfield, P. M., i Gross, E.F. (2001). New forms of electronic media: The impact of interactive games and the Internet on cognition, socialization, and behavior. Handbook of children and the media, 73-99.

Šincek, D., Tomašić Humer, J., i Duvnjak, I. (2015). Navike korištenja interneta i njihova uloga doživljavanju neugodnih iskustva na internetu. U M. Orel (Ur.), EDUvision 2015 »Modern Approaches to Teaching Coming Generation ", Ljubljana, 3rd \& 4th December 2015 - book of proceedings (str. 143-156). Ljubljana : EDUvision, Stanislav Jurjevčič

Šincek, D., Tomašić Humer, J., Duvnjak, I. i Milić, M. (2015). Priroda korištenja informacijskokomunikacijskih tehnologija (IKT) djece i mladeži u Republici Hrvatskoj - nacionalno istraživanje. Završna konferencija projekta „Safer Internet Centre Croatia: Making internet a good and safe place" (neobjavljeno izlaganje).

Tabone, S., i Messina, L. (2010). Personal uses of internet and perceptions of parental mediation: a research with children 10 and 11 years old. Procedia Social and Behavioral Sciences, 2, 2077 2082.

Üneri, O.S., i Tanıdır, C. (2011). Evaluation of internet addiction in a group of high school students: a cross-sectional study. Düşünen Adam: The Journal of Psychiatry and Neurological Sciences, 24(24), 265-272

UNICEF (2008). Iskustva i stavovi djece, roditelja i učitelja prema elektroničkim medijima. Preuzeto 13.02.2017. s http://www.unicef.hr

Valcke, M., Bonte, S., De Wever, B., i Rots, I. (2010). Internet parenting styles and the impact on Internet use of primary school children. Computers \& Education, 55, 454-464.

van den Eijnden, R.J, Spijkerman, R., Vermulst, A.A, van Rooij, T.J, i Engels, R.C. (2010)- Compulsive internet use among adolescents: bidirectional parent-child relationships. J Abnorm Child Psychol, 38(1), 77-89.

Vlček, M. (2016). Ovisnost o računalu kao suvremena bihevioralna ovisnost. Diplomski rad. Zagreb: Edukacijsko-rehabilitacijski fakultet.

Vuletić, S., Jeličić, A., i Karačić, S. (2014): Bioetičke konotacije interneta. Diacovensia, 22(4), 525-558.

Weiser, E. B. (2000). Gender differences in Internet use patterns and Internet application preferences: A two-sample comparison. CyberPsychology and Behavior, 3(2), 167-178.

Ybarra, M. L., i Mitchell, K. J. (2004). Youth engaging in online harassment: Associations with caregiver-child relationships, Internet use, and personal characteristics. Journal of adolescence, 27(3), 319-336. 
Yellowlees, P. M., i Marks, S. (2007). Problematic Internet use or Internet addiction?. Computers in human behavior, 23(3), 1447-1453.

Young, K. S. (1996). Psychology of computer use: XL. Addictive use of the Internet: a case that breaks the stereotype. Psychological reports, 79(3), 899-902.

\section{Parental Control and Behaviour of Children on the Internet}

Abstract: The aim of this study was to examine the relationship between parental control and the gender of the participants with some behaviours on the Internet. There were 388 fourth-grade primary school students who participated in this research. The results have shown that children are more likely to perceive parental control at a high level. Pupils who perceive a higher level of parental control spend more time per day chatting with friends and searching for interesting information, find motivation for accessing the Internet to look for information related to schoolwork and socializing, and post contents on social media more frequently than those who perceive a lower level of parental control. During the canvassing of gender differences, it was discovered that boys more often emphasize they have an open Facebook profile, they spend more time online during workdays and weekends than girls, and they play games, post and search for interesting information more frequently. Besides, they are more likely to find the motivation for accessing the Internet out of boredom and disclose personal information on Facebook, while no differences were determined while perceiving the gender differences. These data can contribute to a better understanding of the parental role in using the Internet with children.

Keywords: social networks, behaviour of children on the Internet, parental control

\section{Elterliche Aufsicht und das Verhalten von Mädchen und Jungen im Internet}

Zusammenfassung: Das Ziel der Untersuchung war es, die Verbindung zwischen elterlicher Aufsicht und dem Geschlecht der Beteiligten im Umgang mit und im Internet zu analysieren. An der Untersuchung nahmen 388 Schüler der vierten Grundschulklasse teil. Die Ergebnisse belegen, dass Kinder strengere elterliche Aufsicht sehr wohl wahrnehmen. Schüler, die sich einer strengeren elterlichen Aufsicht bewusst sind, verwenden mehr Zeit für die Korrespondenz mit Freunden und die Suche nach interessanten Informationen, sie sind motivierter, das Internet für Recherchen für Schulaufgaben zu nützen und sie veröffentlichen häufiger Inhalte auf den Seiten sozialer Netzwerke als Schüler, die eine weniger strenge elterliche Aufsicht wahrnehmen. Beim Vergleich der Geschlechter der Schüler stellte sich heraus, dass Jungen häufiger zugaben, ein Facebook Profil zu haben, dass sie an Wochentagen und am Wochenende mehr Zeit im Internet verbringen als Mädchen, und dass sie mehr Spiele spielen, Inhalte veröffentlichen und nach Informationen suchen. Sie sind auch motivierter, das Internet zum Zeitvertreib zu gebrauchen, um sich auf diese Weise nicht von anderen Kindern zu unterscheiden. Jungen gaben auch häufiger zu, dass sie nicht ohne Internet leben können, während Mädchen das Internet häufiger zum Lernen benützen. Die Ergebnisse ergaben unter anderem auch, dass Jungen häufiger Inhalte auf den Seiten sozialer Netzwerke veröffentlichen und persönliche Angaben bei Facebook posten, während es bei den Kindern, die sich der strengeren elterlichen Aufsicht bewusst waren, keine Unterschiede in Hinsicht auf das Geschlecht gab. Die gewonnenen Informationen ermöglichen es, besser zu verstehen, welchen Einfluss Eltern auf den Internetgebrauch ihrer Kinder haben.

Schlüsselwörter: Elterliche Aufsicht, soziale Netzwerke, das Verhalten der Kinder im Internet 